TOMASZ TUŁODZIECKI, TORUŃ

\title{
PROROK AMOS - HEROLD BOŻEJ KARY I DNIA JAHWE (AM 4,4-13)
}

Prorocy Pańscy znani z kart Starego Testamentu są ludźmi, którzy w sposób bezkompromisowy i zdecydowany obwieszczają wolę Pana i demaskują niewierność Izraela wobec przymierza zawartego na Synaju. W ich ustach ludzki grzech przedstawiany jest jako nieposłuszeństwo Bożym przykazaniom, których najpełniejszy przekaz zawierało Prawo Tory. Jakkolwiek bezkompromisowość w zachowywaniu i obronie Prawa jest fundamentem powołania proroka, to jednak nie wyczerpuje się ono w tej funkcji. Prorocy Izraela nieustannie doświadczają zdrady Bożej miłości. Mimo to nieustannie głoszą niewyczerpane miłosierdzie Pana i Jego nigdy niegasnącą wierność raz danemu słowu. Prorok jest zatem znakiem nadziei. Jak długo jest, trwa i mówi, tak długo działa pośrednik, który pomaga nawiązać zerwany dialog z Bogiem. Najstraszniejsze dla Izraela i każdego wierzącego jest milczenie Boga (Am 9,1-3). A zatem, kiedy prorok mówi, nawet jeśli są to słowa trudne i przerażające, sam Jahwe nadal komunikuje się ze swoim ludem, utrzymując go przy życiu. ${ }^{1}$

W tym kontekście Amos, pasterz z Tekoa, pojawia się na scenie historii biblijnej jako pierwszy prorok, który nie tylko wypowiada konkretne słowa w imieniu Jahwe, ale także zapisuje swoje przesłanie. Dzisiaj bardzo trudne, a wręcz niemożliwe wydaje się rozstrzygnięcie kwestii, jakie teksty wyszły spod jego ręki. Nie ma jednak wątpliwości, że proces tworzenia się tego dzieła rozpoczął się wraz z przepowiadaniem samego Amosa. ${ }^{2}$ Zapisane przez niego słowa oraz praca późniejszych redaktorów tej księgi wyróżnia się

\footnotetext{
Por. M. N o b i l e, Teologia dell'Antico Testamento, Torino 1998, s. 111-113.

2 Por. J. A. S o g g i n, Il profeta Amos. Traduzione e commento, Brescia 1982, s. 30 .
} 
twardością i bezwzględnością, a proroctwo pasterza z Tekoa jest przede wszystkim świadectwem o tragicznym położeniu królestwa Izraela za panowania Jeroboama II. Warto więc zapytać, co dokładnie skłoniło Amosa, mieszkańca południowej monarchii, do wędrówki i interwencji w bratnim królestwie Izraela? Dlaczego ta wizyta spowodowała tak jednoznaczną i bezwzględną ocenę monarchii ze stolicą w Samarii? W końcu, co odcisnęło tak głębokie piętno na Amosie, że właściwie swój cały literacki dorobek przepełnił tak wielką goryczą i smutkiem, iż śmiało można nazwać pierwszym zwiastunem Bożej kary, sądu nad Izraelem?

\section{Księga Amosa - obserwacje strukturalne}

Wśród egzegetów i komentatorów zajmujących się dzisiaj przesłaniem Księgi Amosa panuje duża zbieżność co do zasadniczej struktury wewnętrznej tego dzieła. H. W. Wolff, a po nim także wielu zwolenników jego teorii, twierdzi, że dzisiejszy materiał literacki proroctwa Amosa zawiera trzy podstawowe części: 1. wyrocznie przeciwko obcym narodom (1-2); 2. zbiór przepowiedni przeciw Izraelowi (3-6); 3. cykl wizji (7-9). ${ }^{3}$ Podobnego zdania jest także autor jednego z ostatnich znaczących komentarzy do Księgi Amosa, G. V. Smith, który obok podstawowego podziału, wyróżnia jeszcze krótki epilog w 9,11-15. ${ }^{4}$ Analizując bliżej powyższą strukturę dzieła Amosa, widać wyraźnie, że jest on nie tylko pierwszym prorokiem zapisującym słowa swoich wyroczni, ale także jednym z pierwszych, który na szeroką skalę doświadcza wizji. Stanowią one jedną z najobszerniejszych części jego księgi (7-9). Prorok, nie podając początkowo motywów kary, zapowiada w nich plagi pod postacią szarańczy $(7,1-3)$ i suszy $(7,4-6)$, a następnie przechodzi do

3 Por. H. W. Wolff, Joel - Amos, BK XIV/2, Neukirchen-Vlyun 1985², s. $135-137$.

4 Należy zauważyć, że G. V. S m i t h obok swojej propozycji podziału Księgi Amosa prezentuje bardzo szeroką dyskusją nad strukturą działa Amosa, jak miała miejsce w historii współczesnej egzegezy; por. t e n ż e, Amos, Fearn 1998², s. 14-15. 
napiętnowania korupcji pośród ludu w wizji pionu ołowianego $(7,7-9)$ i kosza pełnego owoców (8,1-3). Serię wizji kończy zapowiedź nadzwyczajnych kar, wieszcząc tym samym całkowitą zagładę Izraela i wielką katastrofę narodu wybranego, która najbardziej wyrazi się tym, że Bóg przestanie komunikować się ze swoim ludem $(8,11-12)$. Wszechobecnym motywem przenikającym zarówno zbiór wizji, jak i całą Księgę Amosa, jest zatem zniszczenie i śmierć. Te tematy literackie towarzyszą czytelnikowi tej księgi na każdym kroku. Jak podają różni komentatorzy tego dzieła, w Księdze Amosa śmierć po prostu widać i czuć. Przenika ona miasta i wsie, uderza zarówno w elity narodu jak i w najsłabszych. Liczba tych, którzy giną, stale narasta, a wszechogarniająca rozpacz zastępuję marzenia i plany o szczęściu i dobrobycie. ${ }^{5}$

Obok wizji, w całym bogactwie literackim zachowanym w Księdze Amosa na szczególną uwagę zasługuje również materiał literacki przedstawiony w Am 4,6-13. Jest to tekst bardzo rzadko komentowany przez autorów. Zawiera on serię pięciu wyroczni zapowiadających niechybną zgubę adresatów, którą wywołają następujące po sobie plagi. Tym samym tematyka Am 4,6-13 dobrze wpisuje się we wspomnianą już tematykę śmierci i zniszczenia w całej księdze.

Serię owych pięciu katastroficznych wyroczni poprzedza krótki dwuwierszowy tekst Am 4,4-5, pełniący funkcję zakończenia dla trzech przepowiedni proroka z Tekoa wymierzonych przeciwko najwyższym autorytetom władzy w Izraelu, które odnajdujemy kolejno w Am 3,9-11; 13-15 i w końcu w 4,1-3. Treść podsumowania owych wyroczni zawarta w 4,4-5, ma charakter liturgiczny. Amos zachęca wręcz swoich słuchaczy do odwiedzenia pradawnych sanktuariów w Gilgal i Betel, pozwala widzieć w adresatach tego tekstu warstwę rządzącą, która odpowiadała za ucisk najbiedniejszych w Izraelu. Prorok z Tekoa nazywa ich „pobożnymi”. Jednocześnie z tekstu Am 4,4-5 wybrzmiewa głęboki sarkazm i ironia, który najlepiej wyraża gra słów: ḥameș -,,przaśny chleb" (Am 4,5) i ḥamaș-,,przemoc" w pierwszej wyroczni (Am 3,10). Podkreślają one aktywny charakter

5 Por. B. M a r r o n c i n i, Profeti e Apocalittici, Torino 1994, s. 71. 
królewskich ośrodków kultu, które z miejsc świętych, gdzie należało składać ofiary Panu (m. in. pokarmowe), stały się miejscami zatracenia. $^{6}$

Pewna grupa komentatorów jest zdania, że wiersze Am 4,4-5 nie tylko kończą sekcję trzech wyroczni przeciwko bałwochwalstwu możnych i wpływowych mieszkańców północnego królestwa, lecz stanowią jednoczesne wprowadzenie do nowej jednostki literackiej, czyli wspomnianego wyżej zbioru pięciu przepowiedni zwiastujących nieuchronne kary dla Izraela. Wiersze te (Am 4,4-5) byłyby również autentyczną wypowiedzią samego Amosa. ${ }^{7}$ Sama kompozycja pięciu wyroczni - kar jest natomiast redakcyjnym rozwinięciem wspomnianego wstępu wzywającego do podjęcia bałwochwalczych pielgrzymek do Gilgal i Betel. ${ }^{8}$

Elementem charakterystycznym perykopy Am 4,6-13 jest pięciokrotne powtórzenie czasownika šûb - „wracać”, „powracać”, „,nawracać”, zakończone terminem k ûn-,,przygotować się”. Stanowi on antytezę dla zaproszenia opisywanego we wstępie Am 4,4-5, które brzmiało: „idźcie”, „podążajcie” (hebr. bû'). Ta gra słów jest jednoznaczną oceną farsy liturgicznej, jaka rozgrywa się w bałwochwalczych sanktuariach i jedną z ostatnich prób podjętych przez Amosa w celu odwiedzenia Izraelitów od zgubnych praktyk. Należy również zaznaczyć, że tekst Am 4,6-13 wykazuje podobieństwa z innymi wypowiedziami prorockimi w tej księdze. Chodzi tu przede wszystkim o styl wypowiedzi Amosa oparty na kolejnych seriach przepowiedni czy słów. Jest on charakterystyczny dla całej księgi, zwłaszcza dla pięciu wizji proroka w Am 7,1-9,10. Podobieństwa do tekstów wizji Amosa dzieli egzegetów na dwie grupy, z których

6 Por. L. A lon so-S chöke1, J. L. Sicre Di a z, I Profeti, Roma 1996, s. $1102-1103$.

7 Por. A. B. Ern st, Weisheitliche Kultkritik, BThSt 23, Neukirchen-Vluyn 1994, s. 126-127; J. J e r e m i a s, Das Prophet Amos, ATD 24/2, Göttingen 1995, s. $46-47$.

8 Por. W. R u d ol p h, Joel, Amos, Obadja, Jona, KAT XIII/2, Gütersloh 1971, s. 172-173; L. M a r k e r t, Struktur und Bezeichnung des Scheltworts, BZAW 140, Berlin-New York 1977, s. 111-112. 
jedna uważa, że tekst Am 6,6-13 stanowi fragment dawnej liturgii, sięgającej być może czasów przed deportacją do Asyrii, druga zaś widzi w nim redakcyjną notę i komentarz do zniszczenia ołtarza w Betel, w ramach reformy liturgicznej Jozjasza (2Krl 23,16-18). ${ }^{9}$

\section{Wewnętrzna struktura pięciu kar Jahwe (4,6-13)}

W wewnętrznym schemacie tekstu Am 4,6-13 każda wyroczni zakończona jest słowami: ,„aleście do Mnie nie powrócili - wyrocznia Pana". Czyni to z owego fragmentu rodzaj pieśni o pięciu zwrotkach opatrzonej refrenem, których trzy pierwsze wspominają plagi biorące swój początek w naturze: deszcz i susza $(4,7)$; głód nieugaszone pragnienie $(4,6.8)$ oraz zwarzenie i śniedź plonów $(4,9)$. Pozostałe dwie plagi mają charakter historyczny. Pierwszą z nich jest śmierć młodzieńców izraelskich $(4,10)$ i zagłada koni, drugą zaś całkowite zniszczenie kraju na wzór Sodomy i Gomory $(4,11)$. O ile więc przedostatnia plaga ma jeszcze charakter ograniczony i zakłada ocalenie pewnej liczby synów Izraela z wojennej pożogi, o tyle ostatnia klęska nie zakłada właściwie żadnego aktu miłosierdzia ze strony Jahwe. Wykorzystanie motywu plag jest wyraźnym nawiązaniem do tradycji Exodusu, co szczególnie widać w narastającym zniszczeniu, jakie niosą ze sobą kolejne obrazy. ${ }^{10}$ Ostatnie dwa wiersze w perykopie Am 6,6-13 pełnią również wyjątkową rolę. Tekst Am 6,12 jest przede wszystkim ostrzeżeniem przed nadciągającym sądem Pana, stanowi jednak także bezpośrednie przejście do krótkiej doksologii przedstawionej w Am 6,13, która wydaje się celem całej sekcji literackiej Am 6,6-13.

Charakterystyczną cechą poszczególnych kar opisywane w perykopie Am 6,6-11 jest także ich podobieństwo do innych tekstów Starego Testamentu, przede wszystkim do list przekleństw zawartych

9 Por. L. A lon s o-S c hök e 1, J. L. S i c r e D i a z, I Profeti, s. 1104.

10 Por. W. H. S c h m i d t, Die Intention der beiden Plagenerzählungen (Exodus 7-10) in ihrem Kontext, w: M. Ve r v e n n e, Studies in teh Book of Exodus, BEThL 126, Leuven 1996, s. 229. 
w przepisach Tory: Kpł 26 i Pwt 28 (choć w tym drugim tekście podobieństwo jest mniej uderzające). Także w księgach historycznych odnajdujemy jeden znaczący tekst, w którym można dostrzec wyraźny kontakt literacki z proroctwem Amosa 6,6-13. Mowa tu o modlitwie błagalnej Salomona podczas poświęcenia świątyni w 1Krl 8,33-37. Wszystkie trzy wyżej wymienione perykopy różnią się jednak znacząco od tekstu Amosa pod jednym względem. Kary, jakie mogą spotkać naród wybrany, zależą od zachowania przymierza z Jahwe i będą wymierzone w przypadku nieposłuszeństwa i niewierności. ${ }^{11}$ Teksty Tory, a zwłaszcza Kpł 26, mają więc charakter wykonawczy, a ich głównym celem jest pobudzenie Izraelitów do nawrócenia. Poza tym zarówno Kpł 26, Pwt 28 jak i 1Krl 8,33-37 mówią wyraźnie o wierności Boga względem przymierza i kontrahenta, z którym je zawarł. Mimo niewierności Izraela Jahwe pragnie okazać mu nadal swoje miłosierdzie: , ... nie odrzucę ich i nie będę się brzydził nimi do tego stopnia, żeby ich całkowicie zniszczyć i zerwać moje przymierze z nimi, bo Ja jestem Pan, ich Bóg. Przypomnę sobie na ich korzyść o przymierzu z ich przodkami, kiedy wyprowadziłem ich z ziemi egipskiej na oczach narodów, abym był ich Bogiem. Ja jestem Pan!" (Kpł 26,44-45). ${ }^{12}$

Dla porównania, błagania króla Salomona zawierają także klauzulę na wypadek odstępstwa narodu wybranego od warunków przymierza. Chociaż król uważa za słuszną sprawiedliwą karę za niewierność, to jednak wskazuje również drogę, która może wybłagać ludowi ponowną przychylność Jahwe. Są to kolejno: nawrócenie, uwielbienie Bożego imienia i gorąca prośba o miłosierdzie $(1 \mathrm{Krl}$ 8,33-34). ${ }^{13}$ Wydaje się, że obie tradycje, zarówno ta opisywana przez Księgę Kapłańską, jak i tekst z pierwszej Księgi Królewskiej, swój

11 Por. H. W. W olff, Joel - Amos, s. 252.

12 Por. K. E 11 i g e r, Leviticus, HAT 4, Tübingen 1966, s. 379; E. S. G e r s t e n b e r g e r, Das 3. Buch Mose. Leviticus, ATD 6, Göttingen 1993, s. 389-390.

13 Por. M. N o t h, Könige, t. I: I Könige 1-16, BK. AT IX/1, Neukirchen-Vluyn $1983^{2}$, s. 173-174; V. F r i t z, Das erste Buch der Könige, ZBK 10/1, Zürich 1996, s. 93-94. 
ostateczny kształt otrzymały już po niewoli babilońskiej i zawierają elementy liturgii pokutnej, która swoimi korzeniami sięga diaspory żydowskiej na wygnaniu wśród tzw. $b^{\mathrm{e}} n e ̂$ gôlăh. ${ }^{14} \mathrm{~W}$ każdym razie drogą do Boga jest nawrócenie i zmiana postępowania. Wobec takiej przemiany Bóg również nie pozostanie obojętny i chce okazać swoje łagodne oblicze.

Porównując listę kar w Am 4,6-11, jakie Bóg zamierza zesłać na niewierny lud, z tekstami Tory i Ksiąg Królewskich, widać wyraźnie, że wypowiedź Amosa ma zupełnie inny charakter. Wszystkie kary Pana opisane w Am 6,6-11, mają identyczne zakończenie i, przynajmniej pozornie, także wymiar pedagogiczny: także one, na pierwszy rzut oka, mają nakłonić mieszkańców Izraela do nawrócenia. Należy jednak zwrócić uwagę na fakt, że tekst Am 6,6-11 ma wyraźnie retrospektywny i zamknięty charakter. Amos przedstawia w nim fakty już zaszłe i dokonane. Mówi o groźbach, z których żadna nie odniosła właściwego skutku. To, co w $1 \mathrm{Krl} 8,33-37$ jest dla króla Salomona wciąż otwartą drogą powrotu Izraela do Boga dla Amosa jest już przeszłością i niewykorzystaną szansą. Potwierdzeniem tej prawdy jest opis piątej plagi podanej przez Amosa, dotyczącej Sodomy i Gomory, a której próżno szukać we wspomnianych wcześniej opisach: Kpł 26; Pwt 28 i 1Krl 8,33-37. ${ }^{15}$ Wskazanie na zniszczenie Sodomy i Gomory stanowi więc zwieńczenie każącego działania Jahwe.

Wyrażenia: ,jak w zagładzie Sodomy, Gomory” (Pwt 29,22); „stanie się jak Sodoma i Gomora, gdy ją Bóg wywrócił” (Iz 13,19); „,jak po zburzeniu Sodomy i Gomory” $(\mathrm{Jr} 48,18)$ czy w końcu ,gdy Bóg zburzył, Sodomę i Gomorę" (Jr 50,40) wskazują zawsze na ostateczną zagładę i totalny charakter zniszczeń tej rzeczywistości. W tekstach, które wzmiankują lub porównują daną rzeczywistość do

14 J. J e r e m i a s zauważa dodatkowo, że tekst modlitwy Salomona nawiązuje do elementów liturgii postnej; por. t e n ż e, Der Prophet Amos, s. 52.

15 Większość egzegetów jest zdania, że tekst Am 4,6-13 powstał na bazie tekstu $1 \mathrm{Krl} 8,33-37$. Dyskusję na ten temat prezentuje E. Gerstenberger, który obok Am 6,4-13 także fragment Kpł 26 uważa za rozwinięcie 1Krl 8,33-37; por. E. S. G e r s t e n b e r g e r, Das 3. Buch Mose. Leviticus, s. 377-378. 
zagłady Sodomy i Gomory można odnaleźć informacje „o miastach, które na zawsze pozostaną niezamieszkane" (Iz 13,19; Jr 49,18; 50,40) $\mathrm{i}$ „o ruinach miast, które nawiedzać będą dzikie i nieczyste zwierzęta” (Iz 13,19; Jr 50,40). Dodatkowo tekst Pwt 29,22 podaje obszerną informację o tym, że kraj spustoszony na wzór Sodomy i Gomory na zawsze pozostanie skażony, spalony i nieczysty, a przede wszystkim całkowicie bezpłodny. Nie wyrosną tam nawet chwasty. Porównanie Izraela do zniszczonej Sodomy i Gomory w piątej zwrotce opisu kar Amosa ma podkreślić z niczym nie dający się porównać obraz totalnej zagłady narodu wybranego bez nadziei na odbudowę, ratunek i miłosierdzie. ${ }^{16}$

\section{Symbol „nadpalonych glowni” w perykopie pięciu kar Jahwe}

\section{$(6,11)$}

Bliższa analiza ostatniej groźby Amosa w 6,11, przedstawiająca obraz całkowitej zgłady Izraela na wzór Sodomy i Gomory zawiera jednak jeden bardzo zaskakujący szczegół, który może sugerować odejście Amosa od wszechobecnej koncepcji śmierci i zagłady jako kary za niewierność, ucisk najbiedniejszych i odstępstwo od zasad przymierza z Jahwe. We wszystkich tekstach Starego Testamentu, mówiących o Sodomie i Gomorze, obraz zagłady tych miast jest ostateczny i bezwzględny. Amos wyłamuje się z koncepcji całkowitego wyniszczenia i wskazuje na bliżej niezidentyfikowaną grupę częściowo ocalonych z tej masakry. Ukrywa ją pod nowym zaskakującym symbolem, który określa jako „głownię wyciągniętą z ognia” ('ûr mūsș̣āl mišrēpāh). Kontrast pomiędzy pierwszą częścią wiersza 6,11, która wskazuje na bezwzględne i każące działanie Pana (,spustoszyłem was, jak podczas

16 Warto zauważyć, że również tekst Iz 1,7 nawiązuje do zniszczenia Sodomy i podkreśla całkowitą zagładę tego miasta. Zaskakujące w tym tekście jest jednak to, że autor nie wymienia drugiego z grzesznych miast, czyli Gomory. Komentatorzy tego tekstu wskazują jednak na fakt, że informacja o Sodomie w wierszu Iz 1,7 ma charakter wtórny, co potwierdza aparat krytyczny BH. Zgodność z opisem Amosa dotyczy przede wszystkim kwestii całkowitego spalenia miasta. Por. H. W i ld b e r g e r, Jesaja I. Kapitel 1-12, BK. AT X/1, Neukirchen-Vluyn 19802, s. 19. 
Bożego spustoszenia Sodomy i Gomory”), a drugą wskazuje na ocalenie niektórych (,staliście się jak głownia wyciągnięta z ognia”); ma na celu wzbudzenie świadomości u tych, którzy przeżyli, że ich ocalenie ma charakter nadprzyrodzony czy wręcz cudowny.

Etymologia słowa ,głownia” ('ûr) dotyka rzeczywistości związanej z ogniem, a czasownik 'ûr oznacza „palić”. W koniugacji hiphil czasownik 'ûr wiąże się z czynnością podkładania ognia czy podpalania. W tym kontekście rzeczownik ten oznacza kawałek drewna włożony do ognia, aby go podsycać. Ten sam przedmiot wyjęty z ogniska czy dogasającego pożaru, jest zawsze symbolem znacznego uszkodzenia czy wręcz bezpowrotnego zniszczenia. Doskonale obrazuje to inny tekst z użyciem terminu 'ûr. Mowa tu o przepowiedni przeciwko Pekachowi i Rezinowi w Iz 7,4, którzy zostali przez Izajasza przyrównani do dwóch dopalających się ,głowni” („niedopałków”), a obraz ten wieszczy ich niechybny upadek. ${ }^{17} \mathrm{~W}$ tekście Am 6,11 ci, których określa się rzeczownikiem 'ûr, doświadczyli właśnie sądu Bożego na własnym ciele i choć nie są jeszcze całkowicie zniszczeni, nie przedstawiają już wielkiej wartości. Jak podkreśla Amos zostali oni „wyciągnięci” bądź ,wydobyci” z trawiącego wszystko ognia. Amos zastosował tu czasownik nāṣal użyty w koniugacji hophal. Podkreśla on wyraźnie, że uratowani sami nie byli w stanie uratować się z katastrofy, i że dokonał tego ktoś drugi. Cały kontekst tej wypowiedzi każe myśleć zatem o użyciu w Am 6,11 formy passivum divinum, którego celem jest ostateczne pouczenie cudownie ocalonych $i$ adresatów tego tekstu.

Poza Am 6,11 czasownik $n$ ạșal występuje w całej Księdze Amosa tylko w Am 3,12. Jest to wyjątkowy tekst, gdzie autor zastosował ten termin dwukrotnie i to w dwóch różnych koniugacjach niphal i hiphil. Mówi on symbolicznie o akcji ratunkowej pasterza, który wyrywa resztki swojego inwentarza z paszczy lwa: „Tak mówi Pan: Tak jak pasterz z lwiej paszczy ratuje tylko dwie nogi albo koniec ucha, tak nieliczni uratowani będą synowie Izraela..." Podobnie jak w tekst Am 6,6-13, także i ta wypowiedź proroka z Tekoa poprzedzona jest,

17 Por. S. A a le n, 'ôr, w: TDOT, I, s. 148. 
zaproszeniem do odbycia bałwochwalczej pielgrzymki. Nasuwa się tu podobieństwo do tekstu Am 4,5-6. Tekst przepełniony jest także gorzką ironią i sarkazmem, gdyż ratunek, o jakim mowa w Am 3,12, jest tak znikomy (fragment ucha i dwie nogi). Tym samym nie może być już mowy o jakiejkolwiek nadziei na wybawienie. Nikłe szczątki, jakie pozostały pasterzowi z całego dobytku, są, zgodnie z przepisami Prawa, zaledwie koniecznym dowodem na to, co dzikie bestie dokonały z jego stadem ( $\mathrm{Rdz} 31,39$; Wj 22,9-12). ${ }^{18}$ Paradoksalnie jednak pozostawione resztki świadczą również o tym, że całkowite zniszczenie dopiero nadchodzi.

Zatem, gdy Amos w 4,11 wykorzystuje ten sam obraz dotyczący resztki ocalałych, czyli tym razem na pół spalonych drewnianych polan, to tym samym pragnie podkreślić, że ich los jest już przesądzony. Co prawda symboliczny obraz nadpalonych głowni sugeruje, że z uratowanych od ognia kawałków drewna większa lub mniejsza część nadaje się jeszcze do ponownego użycia, ale ich wartość jest właściwie znikoma lub żadna. W tej kwestii tekst Am 4,11 jest nawet mniej drastyczny aniżeli Am 3,12. Mimo że resztki, które ocalały z pożogi nie przedstawiają większej wartości, to jednak Boża łaskawość pozostawiała jeszcze drobną szansę na wybawienie, choć wiąże się ona z sądem i jest daleka o perspektywy zbawczej, którą gwarantowało zawarte wcześniej przymierze. Bardzo surowa kara, która niewielu wybranym pozostawia szansę na przeżycie powinna być też powodem do zmiany postawy tych, którzy zostali wyrwani z ogniowej tragedii, jednak ta pedagogiczna inicjatywa Jahwe pozostaje, zgodnie z zakończeniem tekstu Am 4,11, bezowocna.

W poszukiwaniu ostatecznego znaczenia tekstu Am 4,11 warto zwrócić uwagę także na znaczące podobieństwa tego obrazu z trzema innymi wypowiedziami proroka. Dotyczy to następujących tekstów: Am 5,19; 6,8-9 i 9,1-4. Wprawdzie nie chodzi tu o dosłowne podobieństwo terminologiczne, lecz o samo przedstawienie faktów. We

18 Według tradycji kończyny i kawałek ucha służyły pasterzowi za dowód przed właścicielem stada, gdy zostało ono rozszarpane przez drapieżniki (Rdz 31,39); por. L. A 1 on s o-S c hök e1, J. L. S i c r e D i a z, I Profeti, s. 1101. 
wszystkich trzech obrazach chodzi o wykonanie wyroku na pozostałej przy życiu niewielkiej reszcie ocalałych. Dotknięci są zarówno mieszkańcy jednego domu $(5,19)$ jak i całego miasta, z którego zdoła ujść z życiem zaledwie symbolicznych dziesięciu (9,1-4). Ocaleni potrafią początkowo umknąć przed sądem, lecz następna konfrontacja z Bogiem, w każdej z wymienionych scen, opisuje śmierć tych, którzy przeżyli pierwszą egzekucję. ${ }^{19}$ Obraz „,nadpalonych głowni” mieści się również w tej koncepcji. Jak wynika z tekstu Am 4,11, niewielka grupa wybranych, ukryta pod obrazem nadpalonych głowni, została cudownie ocalona w pierwszej odsłonie sądu i otrzymuje od Boga jeszcze jedną, nikłą szansę nawrócenia. Ten sam wiersz stwierdza jednak, że ta szansa została prawie natychmiast zmarnowana.

Jak już zostało wcześniej wspomniane, tekst Am 4,11 odnosi się przede wszystkim do przeszłości i do szansy na nawrócenie, jaką otrzymał Izrael do Jahwe. Nie została ona należycie nie wykorzystana. Teraz prorokowi pozostaje przygotowanie go na niechybne spotkanie z samym Jahwe. Szczegóły tego spotkania przed majestatem Boga przedstawia tekst Am 6,12. Sam opis kar dla Izraela w tym krótkim tekście jest zaskakująco ogólny i zdawkowy: „Tak uczynię tobie, Izraelu, a ponieważ ci to uczynię, przygotuj się, by stawić się przed Bogiem twym, Izraelu!" Trudno jednoznacznie stwierdzić, do czego odnosi się w tym fragmencie początkowe köh („tak”), jak również zaimek wskazujący zö’t („ten”, „to”). Niektórzy egzegeci sugerują, że prorok mówi tu o zniszczeniu sanktuarium w Betel. ${ }^{20} \mathrm{~W}$ tym przypadku wiersz ten musiałby być redakcyjnym dodatkiem, dołączonym do całości dzieła już po reformie Jozjasza (ok. 620 r. przed Chr.). Bardziej przekonującą jest jednak teoria, która widzi w zapowiadanych przez Amosa karach nawiązanie do

19 Por. W. H. S c h m i d t, Zukunftsgewißheit und Gegenwartskritik, BSt 64, Neukirchen-Vluyn 1973, s. 20.

20 L. A lon s o-S c hök e 1; J. L. S i c r e D i a z mówią tu po prostu o jakimś fakcie, który wydarzył się dosłownie ,,poza tekstem”, który jednak był dobrze znany słuchaczom tej wypowiedzi Amosa. Być może był to nawet naoczni świadkowie tych wydarzeń; por. c i ż, I Profeti, s. 1104. 
symbolicznych miast: Sodomy i Gomory, pojawiających się w bezpośrednim kontekście opisu sądu (Am 6,12). ${ }^{21} \mathrm{~W}$ tym przypadku chodziłoby o perspektywę redakcyjną jeszcze późniejszą w czasie, która w obrazie ocalonej chwilowo reszty („,nadpalone głownie”) zapowiada całkowite unicestwienie narodu, kojarzone historycznie z początkiem niewoli babilońskiej w 586 r. przed Chr. Adresatami tych słów byliby zwłaszcza ci spośród narodu wybranego, których nie objęły deportacje w 597, 586 i 582 r. przed Chr.

\section{Dzieło Amosa a redakcja deuteronomiczna}

Zakończenie sekwencji pięciu kar Jahwe dla Izraela ma formę krótkiego hymnu bądź, jak uważają niektórzy egzegeci, doksologii. Wychwala ona Bożą moc działającą w stworzeniach i w historii. Wskazuje wprost na poszczególne czyny Jahwe, które dla proroka Amosa są jednocześnie Bożą przestrogą dla narodu wybranego. Jahwe to ten, któremu podporządkowana jest cała natura: góry, wichry, świt i ciemność. Tych sił może on użyć przeciw tym, którzy nie dochowują zawartego z nim przymierza. Ponieważ wiersz Am 6,13, jak również poprzedzająca go wypowiedź o powtórnym sądzie i definitywnej karze dla ocalałych z katastrofy znaczącą różnią się od pozostałych wypowiedzi Amosa w Am 6,6-11, przypuszczano, że są one późnym dodatkiem redakcyjnym. ${ }^{22}$

Być może zamiarem ostatniego redaktora była jeszcze jedna próba przekonania ocalałych $(6,11)$, do radykalnej przemiany życia wobec nadciągającego sądu Jahwe $(6,12)$ przez wyznanie wiary w jego wszechmoc słowami uroczystej doksologii $(6,13)$. W tym przypadku odrzucenie Bożego ostrzeżenia będzie oznaczało nie tylko śmierć poszczególnych osób, ale rzeczywiście totalną zagładę całego narodu. Wydaje się jednak, że taka interpretacja Am 6,12-13 w kontekście całej perykopy Am 6,6-13 nie ma uzasadnienia w tekście. Zarówno w pięciu zapowiedziach kary, jak i w redaktorskim zakończeniu

21 Por. H. W. W o $1 \mathrm{f}$ f, Joel - Amos, s. 256-257.

22 Por. J. J e r e $\mathrm{m}$ i a s, Die Mitte des Amosbuches, w: t e n ż e, Hosea und Amos, FAT 13, Tübingen 1996, s. 206, 212. 
perykopy Am 6,6-13 trudno znaleźć przesłanie o nowej szansie dla Izraela, o poprawie losu czy nadziei. W tej perspektywie nazwanie Amosa prorokiem śmierci i zniszczenia jest w pełni uzasadnione.

Nie brakuje również komentatorów, którzy ostateczną redakcję Księgi Amosa pragną umieścić w kręgu autorów deuteronomicznych Przez wybór bardzo drastycznej tematyki i symboliki Amos różni się jednak znacząco od całego ruchu i piśmiennictwa deuteronomicznego, np. od Jeremiasza (Jr 31,31-34) czy Deuteroizajasza. ${ }^{23}$ Za powiązaniami z tradycją deuteronomiczną przemawiałoby nawiązanie w tekście Am 6,6-13 do stosunkowo późnych redakcyjnie fragmentów: Kpł 26; Pwt 28 i 1Krl 8, 33-37, z który dwa ostatnie niewątpliwie nawiązują do teologii deuteronomicznej. Jednak różnice w rozumieniu nawrócenia i przebaczenia ze strony Jahwe, o których wcześniej była mowa, każą ostatecznie umieścić tekst Amosa 6,6-13 w innej perspektywie teologicznej i historycznej.

Wprawdzie perykopa prezentująca serię Bożych kar wraz z pięciokrotnym odrzuceniem wezwania do nawrócenia dotyka tematycznie idei opisywanych przez twórców teologii deuteronomicznej, jednak w jednym punkcie dzieło Amosa odbiega od nich zasadniczo. Autorzy deuteronomiczni, zarówno w księgach historycznych jak i prorockich, właśnie w prorokach widzieli heroldów nawołujących Izraelitów do przemiany życia i nawrócenia. W historii deuteronomicznej Jahwe objawia najpierw swój plan działania powołanym przez siebie prorokom, a dopiero potem bywa on wcielany w życie. Amos w swoim przekazie pomija rolę prorockiego słowa w tym procesie, oddając pole bezpośredniej ingerencji Jahwe w bieg historii i procesy natury. ${ }^{24}$ Jest to, według Amosa, ingerencja surowa i bezwzględna, bez cienia miłosierdzia i zmiłowania. Właśnie brak miłosierdzia względem tych, którzy złamali przymierze, oddali się kultom bałwochwalczym i podeptali prawa najuboższych, jest charakterystyczną cechą Boga Jahwe w Księdze Amosa.

23 Dyskusję na ten temat prezentuje W. H. S c h m i d t, Die deuteronomistische Redaktion des Amosbuches, ZAW 77/1965, s. 169-172.

24 Por. H. W. Wolf f, Joel-Amos, s. 137. 


\section{„Reszta ocalonych” w kontekście „dnia Jahwe”}

Drastyczna perspektywa dla narodu wybranego, jaką kreśli w swoim dziele prorok z Tekoa wypływa z centralnej idei tej księgi, którą jest sąd Boży. Dotknie on zarówno samego Izraela, jak i ościenne narody. Ten sąd dotknie z czasem także samo królestwo Judy, z którego pochodził Amos (Am 1,3 - 2,16). Powodem, dla którego Jahwe będzie sądził ludy w tak drastyczny sposób są zbrodnie popełnione wobec najsłabszych (wdowy, sieroty, niewolnicy). Dla Amosa nie ma znaczenia pochodzenie tych najmniej uprzywilejowanych. Są wśród nich zarówno Izraelici, jak i przedstawiciele obcych narodów. Sąd Boży nad zbrodniarzami i grzesznikami przyjmuje różne formy, choćby te, o których informuje Am 4,6-13, jednak najbardziej sugestywny jest wśród nich obraz „dnia Jahwe”. Pojęcie „dzień Jahwe” pojawia się w Księdze Amosa po raz pierwszy w całej literaturze prorockiej. Z czasem termin ten wyrażać będzie jedną z najważniejszych idei eschatologicznych Starego Testamentu. To właśnie ta idea sprawia, że pośród proroków piszących przesłanie Amosa jest właściwie całkowicie pozbawione nadziei. Co prawda Izrael zawsze uznawany był za szczególną własność Pana i głównego beneficjenta przymierza zawartego na Synaju, lecz w momencie zerwania tego paktu, Bóg, według Amosa, wypowiedział wojnę Izraelitom i uważa ich za nieprzyjaciół $(3,1-15){ }^{25}$

Mimo przerażającej wizji sądu i bezwzględnej kary, jaką Jahwe pragnie doświadczyć niewierny naród, Amos pozostawia mały promyk nadziei. Nie wypływa ona z symbolicznego obrazu cudownie ocalonych „nadpalonych głowni” (Am 4,11), lecz wiąże się z kolejnym wyjątkowym terminem, który podobnie jak pojęcie „dzień Jahwe” został u Amosa użyty po raz pierwszy w całej literaturze prorockiej.

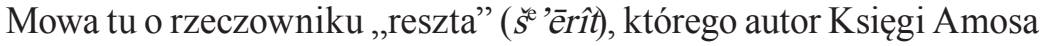
użył dwukrotnie (Am 5,15 i 9,12). Generalnie mówi on o grupie

25 Por. M. L. B a r ré, Księga Amosa, w: R. E. B row n, J. A. F it z m a y e r, R. E. Murphy (red. nauk.), W. Ch ro s t ow s k i (red. wyd. pol.), Katolicki komentarz biblijny, Prymasowska Seria Biblijna 17, Warszawa 2001, s. 826. 
Izraelitów, która przetrwała dzień sądu i ma zapoczątkować nowe królestwo. Według Amosa, jest to grupa bardzo ekskluzywna. Będą ją tworzyć tylko najsłabsi, najbiedniejsi i prześladowani. Wyróżniać ich będą trzy przymioty: 1. poszukiwanie Boga; 2. umiłowanie dobra; 3. praktykowanie sprawiedliwości (Am 4,1-3). Wprowadzenie idei tzw. reszty rozpoczęło również proces postrzegania ubóstwa jako cnoty i konkretnej wartości teologicznej, która z czasem stanie się jedną z nielicznych prawdziwych form prawdziwej żydowskiej pobożności. ${ }^{26}$ Związek między miłością braterską, a miłością do Boga był jednym z fundamentów zawartego przymierza. $Z$ drugiej strony te dwie relacje wyróżniały religię Izraela spośród innych religii i wierzeń starożytnego wschodu. Innymi słowy, jakość relacji Izraela z Bogiem zależała od rodzaju relacji, jakie kultywowali członkowie wspólnoty narodu wybranego między sobą ${ }^{27}$ Niestety, relacje te, w Izraelu współczesnym Amosowi, prorok charakteryzuje jednoznacznie. Wymownym przykładem jest w tym przypadku Am 3,10a, gdzie wspólnotę określa się jako tych, którzy „,nie umieją postępować uczciwie". Zwrot ten bezpośrednio odnosi się do warstw najbogatszych w społeczeństwie, pośrednio także do każdego, kto depcze Prawo Tory, zwłaszcza w trybunałach i sądach, gdzie sprawiedliwość winna być najwyższą zasadą. Tym samym także podeptanie elementarnej sprawiedliwości, zwłaszcza w życiu społecznym, staje się jednym z najważniejszych tematów Księgi Amosa. ${ }^{28}$

Według Amosa, ze względu na podeptanie praw najuboższych i najsłabszych koniec Izraela jest przesądzony i nieodwołalny. Nikt nie jest i będzie w stanie uciec $(5,19)$, gdyż z każdej strony nadchodzi śmierć i zniszczenie. Zasadnicza pewność Amosa co do nadchodzących wydarzeń wyraża się również w szczegółach opisu katastrofy. Prorok mówi tu o „czasie niedoli” ( 'ẹt $\left.d \bar{a} \bar{a}^{\prime} a \bar{h}\right)$ tak wielkim, że żadne stworzenie nie będzie w stanie go zatrzymać i nikt nikogo on nie

26 Por. L. S t a c how i a k, Amos, w: te n że, Wstęp do Starego Testamentu, Poznań 1990, s. 323.

27 Por. M. B a r ré, Amos, s. 274.

28 Por. J. A. S o g g i n, Il profeta Amos, s. 34. 
ominie $(5,13)$. Izrael stanie się jak wielka armia, pozbawiona wszelkiej broni, odarta z pancerzy, osłabiona, a w końcu unicestwiona. Ten moment w historii narodu wybranego można określić jako ,świętą anty-wojnę" (3,11-15). W obliczu tak wielkiego zniszczenia historia świata wydaje się osiągać swój kres. Według znawców zagadnienia, sformułowania Amosa „dzień Jahwe” czy „sąd Boży” (przedstawione na sposób katastroficzny) wskazują na decydującą interwencję Jahwe w bieg historii. Ma ona zatem wszelkie znamiona sądu o charakterze eschatologicznym. ${ }^{29}$

Kolejne etapy profetyzmu izraelskiego korzystały obficie z idei „dnia Jahwe”. Z czasem stał się on synonimem eschatologicznego końca i bywał nazywany po prostu ostatnim dniem czy też ostatnim objawieniem Boga, który ukazuje swoją moc na końcu czasów, niszcząc całe uniwersum. Idea ta w prekursorskiej pod tym względem Księdze Amosa jest na razie tylko zasygnalizowana i swoje pełne rozwinięcie teologiczne osiągnie wraz z rozwojem literatury prorockiej. ${ }^{30}$ Najpierw będzie to kontynuacja obrazu Amosa, w którym Jahwe wyrazi swój gniew wobec synów Izraela. Tak ujmuje teologię „dnia Jahwe” prorok Sofoniasz $(1,15)$. W czasach niewoli babilońskiej funkcja „dnia Jahwe” skoncentruje się na wyrażeniu gniewu wobec wrogów Izraela $(\mathrm{Jr} 46,10)$. Czasy po niewoli babilońskiej przyniosą kolejne dwie odsłony w rozumieniu tej ważnej teologicznej idei. Najpierw Joel przekształci ją w pozytywny obraz zbawienia, którego doświadczy nowy Izrael $(3,4)$. Ostatecznie swój kulminacyjny punkt idea ta osiągnie w przesłaniu Malachiasza, gdzie „dzień Jahwe” stanie się synonimem sądu ostatecznego (Ml 3,10-23).

\section{ks. Tomasz TUŁODZIECKI}

29 Por. A. B o n or a, Amos. Il profeta della giustizia, Brecia 1988, s. 54-55.

30 Por. P. B ov at i, R. M e y e t, Il libro del profeta Amos, Roma 1995, s. $209-210$. 